\title{
C. Douglas Dillon, President Kennedy's economic envoy
}

Aurélie Basha i Novosejt

The Bretton-Woods system, the post-war economic system premised on dollar convertibility, was both an economic arrangement and a political construct. Almost from the outset, the system strained. It nevertheless survived, as Barry Eichengreen has suggested, through an 'interlocking web of political and economic bargains'. ${ }^{1}$ This article focuses on the John F. Kennedy administration and the transition to the Lyndon B. Johnson administration, a time when the system faced its first crisis. ${ }^{2}$ Rather than focus on the economic issues during that period, as many have already done, the article focuses on individuals principally the Secretary of the Treasury C. Douglas Dillon and his role in garnering the political will that was necessary to sustain the system. Dillon exerted influence directly by liaising with key stakeholders in domestic and European financial circles and indirectly by winning over Kennedy to his economic views. Dillon moved Kennedy towards a more fiscally conservative position than his successor would later take. In turn, Kennedy's perceived economic prudence was key to securing cooperation from European allies just as his successor's perceived fiscal irresponsibility had the opposite effect. Unlike diplomatic historians who have largely focused their attention on inter-state relations, this article suggests that private actors were also important. ${ }^{3}$ Dillon and his Undersecretary for Monetary Affairs Robert Roosa were able to leverage their personal networks in European and US financial circles in order to secure the help of internationalist businessmen, most notably David Rockefeller, to great effect.

By focusing on the bilateral relations between Treasury officials and their counterparts in Europe as well as their contacts in the private sector, the article provides a different lens under which to consider Eichengreen's 'bargains'. In so doing, it sheds light on the timing of France and others' eventual challenge on the dollar's role in international monetary relations. In addition, since Robert Roosa's papers have yet to be processed by the John F. Kennedy Presidential Library, the article suggests that the topic of cooperation during the Bretton-Woods era remains a ripe area for research. Using newly-available presidential recordings, the full set of Douglas Dillon's personal papers (including memoranda of his telephone conversations) and files from the Rockefeller archives, the 
article sheds additional light on the Treasury Department's role in sustaining the Bretton Woods system during tumultuous years.

To date, the literature on cooperation during the Bretton-Woods era has focused relatively more on inter-state relations and especially on Franco-American relations. Most historians have suggested that French President de Gaulle's opening salvo against dollar hegemony in February 1965 represented an 'emotional bias' towards his Anglo-Saxon rivals. ${ }^{4}$ For them, de Gaulle's challenge on the dollar had political roots: as Frank Costigliola writes, 'the disputes over political and military issues spilled over into economic relations. ${ }^{5}$ In reality, political and economic realities were indistinguishable. While these historians are correct in seeing escalation in Vietnam as an important trigger in de Gaulle's challenge on US leadership, the problem was not the war itself but rather the economic implications of the war. The latter was seen as a symptom of President Johnson's lack of economic discipline. ${ }^{6}$ Ignoring Dillon and Secretary of Defense McNamara's warnings, Johnson demonstrated a largesse towards allies that they had not seen with Kennedy. ${ }^{7}$

Finally, some historians have spoken about the salience of economic ideas and about the change in power balance within the French administration to explain the change in transatlantic cooperation on monetary issues in the Johnson administration. For them, the rise of the economist Jacques Rueff's and Foreign Minister Couve de Murville's influence on de Gaulle over more Atlanticist officials such as Wilfrid Baumgmartner and his successor as Minister of Finance, Valéry Giscard d'Estaing, was a significant variable. ${ }^{8}$ In fact, as John Odell has shown, a shift in power occurred in the United States as well, with Dillon's relegation from a preeminent to a secondary role in the transition from Kennedy to Johnson and eventually with his and Roosa's replacement with Henry Fowler and Frederick Deming respectively. Mirroring explanations for the French shift, Odell claims that the change in personnel was important because it signalled that Robert Triffin's views on the Bretton Woods system, that were more radical than Dillon and Roosa's, were on the ascendant. ${ }^{9}$

The article builds on Odell's work insofar as he rejects that changes in monetary policy during this time were 'explainable as an acquiescence to international market pressures as conceived in conventional theory', in other words by impersonal forces, or by domestic pressures. As he does, the research here suggests that agents, President Kennedy, Dillon and Roosa, were important. Whereas for Odell agents were only important insofar as they carried with them ideas on reforming the international monetary system, here the 
suggestion is made that actors were important in their own right as stabilizing forces. Similarly, the article adds to Erin Mahan and Francis Gavin's work that shows that France was remarkably cooperative on economic issues and was not a knee-jerk challenger to US hegemony. ${ }^{10}$ It adds private actors to the list of 'challengers'. The article makes a first step towards filling a gap in the existing literature on the role of private actors during this period. There is a dearth of works on the Kennedy administration's relations with the business community although many in the administration were more concerned about Wall Street than they were about European allies. ${ }^{11}$

\section{[Insert Figure 1 here]}

\section{Dillon at the Treasury Department}

Dillon was a revealing choice as Secretary of Treasury. He began his career at his father's investment bank Dillon, Read \& Co. and only reluctantly took on its Chairmanship after wartime service. ${ }^{12}$ The bank was at the centre of the revolving door between government and business: its alumni included Paul Nitze and the first US Secretary of Defense James Forrestal. Instead of banking however, Dillon preferred a career in government and swiftly left banking to join the Eisenhower administration where he served as Ambassador to France and then Undersecretary of State for Economic affairs. In the latter role, Dillon's views echoed Kennedy's campaign messages. In particular, he became an advocate for a 'substantially increased economic aid' program in the 'less developed areas' of the world, which he thought would become 'the principal battlefield in the Cold War'. ${ }^{13}$ Despite rhetorical similarities with the Democrat candidate however, Dillon was a staunch Republican. He had campaigned for Republican candidates in each election since 1948 and had been a major donor to the Richard Nixon campaign. ${ }^{14}$

Dillon's privileged upbringing and career gave him access to a powerful network in business around the world. In his oral histories for the Kennedy Presidential Library, Dillon recounted how he had known the Chairman of the Federal Reserve William McChesney Martin 'for some 25 years, long before he ever came to work for the government', how the influential columnist Joseph Alsop was an 'old friend of mine in boarding school and college' (as were the Rockefeller brothers), how Senator William Fulbright was a 'very good friend' and how he had maintained cordial relations with de Gaulle during the General's wilderness 
years. ${ }^{15}$ This bipartisan network was a key selling point for his candidacy at the head of the Treasury.

In appointing Dillon to the position, Kennedy insisted that his choice was without political calculations. In their first joint press conference, the President-elect explained that for positions that touched upon the national security of the United States, 'I have attempted to secure the best people available in the United States regardless of their party - men who are united by a common determination to see [...] our strength increased.' Dillon explained how 'the maintenance of fiscal stability of the United States is an essential element of our national security,' that his was an apolitical position. He added, the 'strength of the whole free world is tied with the strength of the dollar, and the fiscal stability of the United States.' When asked how he felt about joining a 'cabinet full of Democrats', Dillon laughed the suggestion off, adding, 'I wouldn't be the only one, Mr. McNamara is with me in that position. ${ }^{16}$

However, Dillon and Kennedy's insistence on 'fiscal stability' during their press conference was a not so subtle indication that actually, Dillon was a political appointment designed specifically to reassure Republicans and allies that their fears of a profligate Democrat president were unfounded. During the election, the price of gold had shot up against worries that Kennedy might devalue. In a series of letters to then-Senator Kennedy, the economist John Kenneth Galbraith warned that for the first year since the creation of the Bretton-Woods system, foreign claims on dollars now exceeded the country's gold reserves and that the incoming President needed to send a clear message to actors that might provoke a run on the dollar. ${ }^{17}$ Kennedy did so in a speech delivered in Philadelphia in October 1960.

Also, his transition team, which included Paul Nitze, recommended a Treasury Secretary 'who enjoys high respect and confidence in the international financial world' and ideally had previous experience in State. Richard Neustadt narrowed the candidates down the list to Robert Lovett, John McCloy and Dillon. He admitted that the administration would probably end up with a Republican, which would provide the 'symbolisms of bipartisanship and fiscal responsibility rolled into one. ${ }^{18}$ A separate McKinsey study agreed. It explained that the Secretary's main role was to be a spokesperson to Congress and financial interests, which tended to be overwhelmingly Republican. ${ }^{19}$ 
The bipartisan and reassuring choice of Dillon was not without its detractors. While Galbraith might have been 'euphorically insistent', and Dillon's old friend Joe Alsop 'equally impassioned' about Dillon, others were concerned. ${ }^{20}$ Robert Kennedy speculated that he could later resign loudly and embarrass the administration. ${ }^{21}$ Arthur Schlesinger worried that someone like Dillon would scuttle liberal dreams. He wrote, 'The gold crisis makes Treasury especially critical, since the orthodox answer would be to reduce public spending and increase the interest rate, and the crisis would therefore reinforce all Dillon's natural inclinations. $^{22}$ Senator Albert Gore, who had campaigned with Kennedy against Eisenhower's conservative economic policies, was especially furious. ${ }^{23}$ 'Such an appointment,' he warned, 'would be a signal that you have given up the goals of a truly Democratic Administration. ${ }^{24}$ Gore also warned that Dillon would skew the administration's policy, pushing an 'ultra-conservative policy wrapped up with pseudonyms and labels to make it appear as liberal policy. ${ }^{25}$

To some extent, Gore was correct. Much as Dillon played up his conversion to Keynesianism in office, he continued to encourage fiscal conservatism as he emerged as a key advisor to Kennedy. Kennedy's other economic advisors bemoaned the fact that Dillon had 'the greatest influence on economic policy of all Cabinet members' and indeed that he carried such weight 'beyond economics and finance' as the President and he became particularly close. ${ }^{26}$ As news reports at the time noted, to some extent Dillon's positions on economic issues were a reflection of the Treasury Department itself, a 'big and bureaucratic, banker-oriented and debt conscious' institution, but it also reflected Dillon's personal take on the problems confronting the United States, a view he shared with the President. ${ }^{27}$

As Galbraith had intimated during the campaign, the start of the Kennedy administration coincided with the first period after the war during which the United States felt a tension between its domestic ambitions and its global responsibilities. Despite the administration's best efforts to encourage trade, overseas operations and foreign access to American capital produced a persistent balance of payments deficit. This was a result of government actions and of private capital outflows. Yet in the face of a lagging domestic economy, the administration could not increase interest rates. Robert Triffin, the Yale economist, gave his name to this core dilemma: to resolve the balance of payments, the United States should have increased interest rates but as a reserve currency, it could not do 
this without also choking off liquidity that was necessary for growth at home and in allied economies in the absence of alternative capital markets abroad.

As a result, Dillon and Roosa went to work with Allies on a number of short-term steps alongside secret longer-term planning for 'corrective action' including studying alternatives to the dollar-gold peg. ${ }^{28}$ Roosa played a central part in flagship steps, including in the so-called 'Roosa bonds' that were denominated in foreign currencies; in the creation of a London gold pool that was designed to buffer against changes in the price of gold and in strengthening the IMF's contingency arrangements. ${ }^{29}$ In addition, Dillon pressured other government departments - chiefly the Defense Department - to reduce overseas outlays and to pressure Allies to 'offset' dollar costs of US operations. He became the public face of the Interest Equalization Tax (IET), which de facto taxed foreign access to US capital by taxing US investors' foreign securities purchases. Critics, which included Triffin, derided these as mere 'palliative' actions but nevertheless subsequently accepted that they 'postponed the day [of reckoning] longer than I would have expected.' 30

In Dillon's correspondence with President Kennedy, what is remarkable is how much of this cooperation remained secret to even senior members of the administration and how many internal debates Dillon won. He overruled the Council of Economic Advisors (CEA) and other economic experts on virtually all main economic points of contention, including the timing and pace of the tax cut bill and in delaying public works spending. During a key Cabinet-wide discussion on the balance of payments in September 1963, Dillon and Galbraith dominated the discussion. ${ }^{31}$ Throughout this period, where the more academic economists in the CEA recommended a wholesale reform of the Bretton-Woods system, Dillon argued that preserving confidence was critical, that reform would work only after the United States had begun to tackle its balance of payments problems. In July 1961, for instance, Triffin suggested creating a 'super-central bank for creating international monetary reserves. ${ }^{32}$ Dillon dismissed this idea, arguing that 'our feelings were based on practicality. ${ }^{33}$ Similarly, when Triffin's colleague from Yale, James Tobin who was now in the CEA, suggested a 'floating dollar free of gold', it provoked laughter. ${ }^{34}$

Similarly, Dillon frequently overruled the State Department despite saying that his experiences there as Undersecretary under the economic stringency of the Eisenhower administration had made him very conscious of departmental prerogatives. ${ }^{35}$ When Walt Rostow recommended that Kennedy devalue and expressed anger at plans to withdraw 
troops from Europe, Dillon commented, 'This philosophy is the natural reaction of those who find their preferred policies threatened by balance of payments difficulties. ${ }^{36}$ But Dillon had powerful allies as he pushed for troop reductions and other policies aimed at redressing the balance of payments deficit. They included McNamara and Galbraith. Brushing aside State's focus on 'semantics', McNamara suggested to Dillon, 'We shouldn't try to be too fancy with the Germans and the French and pretend that our balance of payments didn't have anything to do at all with this. ${ }^{37}$ Similarly, in pushing for offset agreements, Dillon and McNamara won over Kennedy despite objections from the State Department that such agreements might weaken the perceived US commitment to Allies.

Dillon was able to overrule the CEA and the State Department by convincing President Kennedy that securing business and Allied confidence was of first importance. Liberal critics such as Gore expressed anger at this focus on 'acceptance in the financial community, both international and national, in order to bolster and preserve the confidence in the dollar, confidence in the stability of economic policies.' He equated this position as 'notice to the world that you are going to follow the same policies that Eisenhower followed. ${ }^{38}$ Kennedy publicly dismissed the 'myth' of confidence, notably in the Yale Commencement speech in June $1962 .{ }^{39}$ Yet, in private, he accepted his Secretary's position that securing confidence was a sine qua non condition for other domestic economic programs and for Allies' willingness to countenance reform of the economic system.

For Dillon and Roosa, confidence was only possible by 'avoid[ing] any public expression of undue concern over the gold situations inasmuch as the concern might in itself stimulate capital flight' and, as Gore feared, by demonstrating fiscal prudence. ${ }^{40}$ Not long after the Berlin crisis in September 1961 that had triggered gold hoarding and a further crisis with the British pound in October, Dillon wrote to Kennedy: 'The amount of this loss will depend on how much of their dollar gains foreigners will decide to keep in dollar balances instead of requesting gold. This in turn will depend on the general state of confidence in our overall financial situation which has clearly declined in recent months. To get the trend moving in the right direction again, it is highly important that a strong effort be made to keep the Government's budget deficit this fiscal year as low as possible through substantial administrative reductions in civilian spending. ${ }^{41}$ Dillon repeatedly told the President that long-term reforms to the international monetary system that might make the United States more resilient were only possible by first securing confidence in the 
Democratic President's financial responsibility. He wrote, 'We have got to get our own deficit really well in hand before any of the continental people will be ready for any earthshaking new thing. ${ }^{42}$

In addition, Dillon and Roosa used their networks and clout in the private sector and with Europeans to produce secret back channels. ${ }^{43}$ For Dillon, their secret meetings with European central bankers and government officials were a 'substantial element in the relative strength of the dollar'. ${ }^{44} \mathrm{His}$ correspondence with Kennedy is replete with references to these 'secret' and 'very quiet' contacts. ${ }^{45}$ Later, Roosa ascribed his own need for secrecy to his time at the Federal Reserve that had 'left me with more than a trace of the preference for secrecy and aloofness that has necessarily become traditional in that fraternity. $^{, 46}$

However, what is not clear from their correspondence is whether Kennedy was predisposed to agree with Dillon in the first place. In his oral history, Dillon argued that Kennedy chose him because they agreed on economic policy. He explained, 'He was afraid that there was a lack of confidence in the US and that nobody knew what the new policies would be. He said that I could render substantial assistance because I was known in Europe and was known to believe in the maintenance of the value of the dollar and in a sound dollar, which he very much believed in himself. ${ }^{47}$ Schlesinger saw Kennedy's father's influence in this. 'The elder Kennedy had in particular the business belief in the mystique of "confidence" and used to warn against action or appointments which might impair that sacred commodity,' he wrote. Many colleagues were surprised if not disappointed by Kennedy's inclination to follow the business world's preferred line on fiscal policy. ${ }^{48}$

By contrast, Kennedy's successor was far less fiscally conservative and far more aloof in his relations with Dillon. Within days of Kennedy's assassination, Dillon wrote to Johnson about market turbulence and suggested a reassuring passage for Johnson's first address to the nation. ${ }^{49}$ Johnson used just ten words. Diplomatically, Dillon recalled that Johnson 'had very little interest that I could see, in substance. He may have had it internally, but it never came out. ${ }^{50}$ Instead, the day of Kennedy's funeral, Johnson set a different tone. Schlesinger noted: 'He has assured [Walter] Heller and Galbraith that he is a Roosevelt Democrat, not an Eisenhower Democrat; that he always felt Kennedy to be unduly conservative on fiscal questions; and that he plans to continue and enlarge Kennedy's social and economic programs. ${ }^{51}$ Even as Dillon continued to champion the Kennedy tax cut, which Johnson 
would also speak to in his first speech, he reminded the President that expenditure control was crucial to placate conservative and business fears. ${ }^{52}$

The problem too was that Johnson and his new entourage seemed to ad lib on carefully constructed policies. In December 1963, when Johnson expanded on the country's commitment to keep six divisions in West Germany, Dillon was furious. ${ }^{53}$ He wrote about the 'importance of this matter from a balance of payments point of view' and of the 'psychological effects of our posture on European Finance Ministers and Central Banks' and reminded the President of the 'significant domestic political issue involved. ${ }^{54} \mathrm{~A}$ few months later, Dillon worked with Johnson's assistant Bill Moyers to articulate a press line on the balance of payments, only to find his advice ignored..$^{55}$ Johnson regularly fielded Dillon's calls who complained that when the President called for a cabinet meeting on economic issues, it was 'just a publicity stunt. ${ }^{56}$

Dillon's frustration with Johnson continued to grow into the spring of 1965 when he finally left. In early 1965, when the President made a suggestion about devaluation that landed in the Wall Street Journal, Dillon seethed: 'We have been talking about this for a year and a half; that certainly no suggestion involving a change in the price of gold is acceptable or proper. ${ }^{57}$ Just days before de Gaulle's February 1965 press conference, he wrote to White House staff, 'For god's sake tell everyone not to talk about this problem [...] Talk makes everything worse. ${ }^{58}$ In conversations with his colleagues, he complained about the President's thin skin and lack of diligence on economic issues. In one phone conversation, McGeorge Bundy told Dillon how '[ClA Director] McCone said he thought [...] the President was basically usurping [the Treasury's role] - he thought we ought to stand up to him. ${ }^{59}$ But without direct access to the President, Dillon was ignored.

Ultimately, Johnson refused to heed Dillon's advice that his political largesse had potentially catastrophic economic consequences and that political cooperation from Allies also relied on a series of economic understandings that Dillon had carefully negotiated. A deficit was acceptable to them 'as long as it didn't stay too long,' he warned. ${ }^{60}$ Whereas Kennedy had considered increasing taxes in the wake of the Berlin crisis, Johnson refused to do so as the US commitment to South Vietnam began to escalate. Unlike Kennedy, Johnson did not share European and conservative concerns about balancing the budget and the potential danger of exporting inflation. He was also less willing to adopt or adjust to their views. With Dillon's departure from government, Johnson ultimately lost someone who 
could defend the more conservative view and, with him, access to a well-developed network with the same actors that might precipitate a run on the dollar, especially in France and the American banking community.

\section{French monetary cooperation}

The extensive literature on French monetary cooperation to date has largely focused on a philosophical shift within French government about the role of the dollar in the mid-1960s. Mahan and Gavin, in particular, have focused on the ascent of Rueff and Prime Minister Debré's anger with American 'easy money' and its willingness to export inflation onto international dollar holders. ${ }^{61}$ While de Gaulle's February 1965 speech emphasized these structural concerns and the economic dominance that came from the dollar's central role under the Bretton-Woods system as opposed to a more 'neutral' gold standard, he also reflected on the long-standing cooperation that existed. In his speech, the General spoke of the extensive consultative mechanisms and of overdue and 'preventative' action that should be undertaken in a 'serene' atmosphere. ${ }^{62}$

Mahan has shown that France was overwhelmingly cooperative in the early part of the decade: before 1962, France was one of the few countries that did not convert its dollar reserves into gold. ${ }^{63}$ If anyone, it was Britain that was chastised for its 'totally different attitude from that of the Central Bankers on the continent. ${ }^{64}$ Kennedy only began to complain about the French on monetary issues in 1963. However, even then, Roosa urged the President to see matters from France's perspective arguing that they 'really think they've given enough already' and in particular to consider his ally Giscard d'Estaing who

was 'being made a scapegoat' ${ }^{65}$ Despite some tensions, the American and French positions were never wildly off during Kennedy's time as both sides agreed on the threat that a continued balance of payments deficit posed to the international monetary system. Moreover, Dillon and Roosa regularly extended diplomatic gestures to de Gaulle and to his closest advisors, many of whom were long-time friends. This was no longer true after Roosa and Dillon left the Johnson administration, in January and April 1965 respectively.

Yet, although Dillon and de Gaulle had known each other for some time, whatever warmth they might have had evaporated when Dillon came to the Treasury Department. As Ambassador to France, Dillon, whose family owned a reputed Bordeaux vineyard, had been well-regarded by the Gaullists. He consulted de Gaulle during the latter's years out of 
government and befriended the then-Senator Debré. Later, as Undersecretary of State, Dillon accompanied de Gaulle and his wife for the duration of their trip to the United States in April 1960. In thanking him, de Gaulle wrote of Dillon's 'thoughtfulness and friendship' and expressed his 'high esteem' ${ }^{66}$ However, their 'friendship' did not make Dillon more sympathetic to the French President once he was at the Treasury. Even after de Gaulle's 1965 press conference, Dillon minimized the General's importance suggesting flattery would placate him and that the United States would be best served if it 'operate[d] on the assumption that de Gaulle's leadership of France is temporary. ${ }^{67}$ Dillon's more recent experience at the Treasury working with his French counterparts at the Ministry of Finance encouraged his view that de Gaulle was a temporary, and surmountable, obstacle to cooperation.

Throughout his time in office, Dillon's working relationship with Atlanticists at the Ministry of Finance was able to keep Rueff's influence in check and largely dictated the tone of Franco-American monetary cooperation. Baumgartner and his successor as Minister of Finance, Giscard ensured cooperation and largely bypassed de Gaulle. Dillon addressed both men as 'my dear friend' and maintained a secret channel of communication with them through Ambassador James Gavin. ${ }^{68}$ As he would in every other period of tension, when de Gaulle felt spurned by bilateral talks between UK Prime Minister Macmillan and Kennedy in May 1961, Dillon rushed to 'correct this feeling' and invited Baumgartner to spend time with him in Washington. ${ }^{69}$ Despite initial concerns over Giscard, Dillon found him no less cooperative. On his visits to Paris, on the margins of OECD, IMF or NATO meetings, he dedicated an unusual amount of time to Giscard. ${ }^{70}$

Until 1963, the Finance Ministry actively kept de Gaulle in the dark over international monetary affairs. In the lead-up to Kennedy's visit to France in May 1961, Baumgartner and Dillon agreed to leave technical matters 'in the hands of the financial experts of our two governments' noting that de Gaulle was just 'generally aware' of the problems. ${ }^{71}$ The Bank of France cooperated in hiding relevant information from the President. In one secret meeting with Dillon in May 1962, the Deputy Governor of the Bank of France, Pierre Calvet, told Dillon that de Gaulle was 'not well aware' that a third of its foreign exchange assets were held in dollars and despite tentative enquiries from the Elysée Palace, the 'Bank of France was not anxious to give him detailed information and so far has not done so. ${ }^{72}$ Although the French economic authorities regularly warned that these dollars 'represented 
a political as well as an economic problem', and despite their regular gold purchases, they nevertheless went out of their way to reassure Dillon that they did not wish to undermine cooperation. $^{73}$

For his part, Dillon was also more inclined to make concessions to the French, including on defense matters and notably on nuclear issues. Throughout 1962, American officials tried to encourage their French counterparts to buy more American military goods or to enter into a similar 'offset' arrangement as they were negotiating with the Federal Republic of Germany. Costigliola and others have quoted the memorable quip from one French official, 'You don't want to sell us what we want to buy,' that is, nuclear technology. ${ }^{74}$ However, what emerges from Dillon's documents is how far he, McNamara, McCone and Chairman of the Joint Chiefs of Staff General Taylor, were willing to countenance helping the French, if not on their nuclear program itself, on the associated equipment. ${ }^{75}$ In one conversation, McNamara suggested to Dillon that the President 'agreed with him' but it was the State Department who scuttled his plans. ${ }^{76}$

Transatlantic exchanges between economic authorities during this period provide another insight into the timing of de Gaulle's challenge on the dollar's role in the international monetary system. Despite Dillon and Giscard's best efforts, as well as Kennedy's rhetorical nods to transatlantic cooperation most notably in his January 1963 State of the Union address, the Kennedy administration became concerned about de Gaulle's anti-American positions. Dillon assured Kennedy that de Gaulle would not risk 'destroy[ing] the whole system of international cooperation in the monetary, financial and other spheres', but nevertheless told the President that 'we should have a plan for this."77 Still, and amid calls from the Foreign Ministry to take a tougher stand on the dollar, Giscard brokered compromises with his American 'friend' into 1964, including by pushing forward prepayments on US loans.

Even as French pressure ratcheted up, the cooperative channels between Treasury departments continued to make a difference. In part, this was because the US Treasury's position overlapped with the French one on core issues including the type of action that might be needed to tackle the balance of payments and the excessive role of US capital on European economies. Returning from Europe in December 1961, Roosa applauded the 'complete agreement on the impelling need for the United States to regain balance of payments equilibrium. ${ }^{, 78}$ With a sympathetic President under Kennedy, Dillon led a Cabinet 
Committee charged with tacking the deficit and leveraged the White House's pressure. In March 1963, Kennedy asked the committee if the country was doing enough to convince Europeans to hold their dollars, to which the Treasury responded that if the 'present level [continued] beyond two years,' it 'would not be sustainable. ${ }^{79}$ In particular, Dillon echoed Giscard's concern that the United States might export inflation if it did not keep its budget under control. ${ }^{80}$

A further concern for France was the inflow of American capital, which began to take on nationalist undertones. Whereas the French had courted American capital in earlier years, by 1963 they were running a trade surplus and began to express concern about the economic dominance it represented. The issue took on a symbolic importance in the second half of the decade, with the publication of Jean-Jacques Servan-Schreiber's Le Défi Américain that decried American capitalism as a form of colonization and with de Gaulle himself describing the situation as 'expropriation' during his February 1965 press conference. However, in the Kennedy administration, the concern over capital flows was especially pronounced on the US side as they represented a further dollar drain. The Chrysler takeover of the French automobile company Simca later became a lightning rod for French opposition to American capital but in 1963, it was Kennedy that used it as an example of the type of foreign operations that could also harm the United States' economic standing. ${ }^{81}$ The administration pressed Europeans to develop their own capital markets and, when that failed, passed the IET which essentially taxed international transactions.

With the IET and other concrete policies, including on trade, that addressed the balance of payments problem, the Kennedy administration attempted to placate French concerns. In June 1963, after a phone conversation with Giscard, Dillon noted that he 'closed by saying they were pleased with the trend in the American economy.' ${ }^{82}$ Well into 1964, as the steps initiated in the Kennedy administration began to take effect, the Europeans seemed on board. In May 1964, Dillon found European central and commercial bankers 'much impressed by the improvement in the United States' balance of payments' even as they continued to worry about a 'relapse' and its 'extremely serious consequences for the dollar and for the world in general. ${ }^{83}$ Roosa reassured his IMF partners that 'never again' would the United States 'be slow to realize the payments problems as in 1958-60. ${ }^{84}$ Whereas Roosa's comment might have been true under Kennedy, under Johnson the mood began to change. By 1966, without assurances of fiscal discipline nor the prospect of 
budgetary balance, de Gaulle privately confessed, 'We must wait for the collapse of the dollar. The Americans spend too much on Vietnam, research, and space for their own good. We shall be forced to cover the American deficit. They will take up a collection and our partners will give in to American influence. ${ }^{85}$ There is no way of knowing if Kennedy's policies would have been enough to continue to secure French cooperation nor even if Kennedy would have, or indeed could have, continued to be as fiscally conservative as he had been. Nevertheless, behind the façade of continuity in the transition from the Kennedy to Johnson administrations and, as de Gaulle discerned, a shift occurred.

\section{[Insert Figure 2 here]}

\section{Business and the administration}

The Kennedy administration was ultimately more concerned with the business world, and Republican Wall Street in particular, than it was with de Gaulle. From the administration's vantage point, 'business' was less inclined to cooperation and had more of a political incentive to provoke a run on the dollar. In some respects, the early 1960s were a coming of age moment for Wall Street as capital flows became increasingly internationalized and fluid. Bankers such as David Rockefeller at Chase Manhattan Bank became true global bankers: in the absence of alternative sources of capital abroad, they built up a strong presence around the world and especially in Europe. ${ }^{86}$ By 1969, close to a quarter of Chase's portfolio was abroad. In keeping with its global reach, Chase Manhattan created an International Advisory Committee that would eventually gather some of the foremost public figures of the time, including Dillon, Baumgartner and future Secretary of State Cyrus Vance. ${ }^{87}$ However, most of these overseas operations also represented a drain on the balance of payments and one that seemed less amenable to a diplomatic solution.

In 1960 and for much of the Kennedy administration, a general climate of distrust poisoned relations between business and the administration. Reiterating similar warnings from Roosa and Galbraith, Dillon wrote to Kennedy that the 'biggest danger is not from abroad, the big danger is the Americans' who might provoke a run on the dollar. ${ }^{88}$ American businessmen were also more explicit in essentially blackmailing the administration and tying their cooperation to a quid pro quo on fiscal discipline. Much as Galbraith dismissed the 
bankers as 'on the whole, egotistical reactionaries' who were stuck in 'their always myopic and often medieval instincts,' the administration nevertheless worked to reassure them. ${ }^{89}$

The administration started afoul with the business world. In part, it was a question of form: whereas President Eisenhower's appointments had included 36\% businessmen, Kennedy's only included six. ${ }^{90}$ In lieu of Eisenhower's Cabinet of 'eight millionaires and a plumber', Kennedy's was filled with East Coast intellectuals. Moreover, business fears began to translate into economic outcomes. In April 1962, tensions flared when the steel industry broke with official price guidelines aimed at stemming inflation, and in May of the same year, a stock market crash ended the administration's plans for a balanced budget.

Both sides blamed each other for the stock market's fall. Bankers blamed Kennedy's anti-business streak; the administration attacked the bankers' ill-will towards the administration. Years later, Dillon suggested that Kennedy had been 'treated fairly by everyone with the big exception of the business community. ${ }^{\prime 91}$ In June 1962 , speaking to the Financial Writers Association, Dillon struck a tone that spoke to his previous incarnation as a financier. The speech became a template for all of the administration's speeches thereafter and especially for Kennedy's Yale Commencement speech. 'Panic took control of the great NYSE,' Dillon explained, and expectations - 'the mirage of imminent inflation' - overtook reality. He attacked the 'myth' that government deficits necessarily produced inflation and suggested the crash was the product of a misunderstanding. He noted, 'Another myth that has been current in business circles in recent months is the misconception that the Kennedy administration is pursuing an overall anti-business policy. ${ }^{92}$ It became Dillon's role to correct this misconception.

Writing during the steel crisis, a former partner at Dillon, Read \& Co., wrote to Dillon asking him to 'do your best' to remove the 'semblance of a fight between the administration and 'business'. ${ }^{93}$ This was an uphill battle: one poll suggested that fifty-two percent of businessmen felt the administration was 'strongly anti-business', thirty-six percent 'moderately' so, and only nine percent felt the administration was either neutral or probusiness. ${ }^{94}$ In the face of these alarming poll numbers, Dillon sent Kennedy a study prepared at the Treasury Department that suggested that the 'president's popularity seemed to be very high' but that 'attacks were directed toward the "wild-eyed men" around" him. ${ }^{95}$ Early efforts to change this perception backfired. In his journals, Schlesinger angrily noted, 'There are about ten thousand people in the country involved in this - bankers, industrialists, 
lawyers, publishers, politicians - a small group but doing everything they can to say that we are going into a depression because business has no confidence in the administration. ${ }^{96}$

As Schlesinger noted, the financial press toed the business line as well. Instead of Dillon, Time Magazine put the Chairman of the CEA and the quintessential New Frontier intellectual, Walter Heller on its front page with an ominous chart of a collapsing market as a backdrop. ${ }^{97}$ The Wall Street Journal, in particular, was biting in its criticism of the administration and became a mouthpiece for conservative criticism. Its op-eds were especially critical on the issue of a tax cut. One read: 'Tax cutting is not at all the surest and soundest way to a balanced budget; that way is to reduce the spending. [...] The Kennedy tax program may be fine by itself, but the Government's financial policy as a whole cannot honestly be called responsible. ${ }^{98}$ Dillon, who forwarded pertinent media reporting to the President, appended one favourable Wall Street Journal article with a note that read, 'Mr. President, To be framed for posterity. It may never happen again. ${ }^{\prime 99}$

In the face of this resistance, Kennedy centralized control over the administration's economic message and sent Dillon on a peacebuilding mission as someone who 'could talk as a businessman'. ${ }^{100}$ He instructed his colleagues, 'I don't want anyone to say anything about the domestic economy except for Doug Dillon and myself. ${ }^{101}$ As the administration's envoy to the business world, Dillon got to work reaching out to friends including Thomas Watson Jr. at IBM and the former Secretary of Defense and banker Robert Lovett, who had initially been offered the Treasury job. He resuscitated the Business Advisory Committee whose 'lunches and informal gatherings', he explained to Robert Kennedy, went some way to building up a 'reservoir of good will and understanding'. ${ }^{102}$

Dillon's role as envoy was perhaps most important on the issue of tax reduction and the administration's key ally from Wall Street on this issue was David Rockefeller. Dillon influenced the public relations aspects of the tax cut and also its timing. Significantly, the first tax cut that passed during the Kennedy administration was a change to depreciation rules, which essentially allowed businesses to lower their operating costs. The broader program of income tax reduction was delayed in light of 'other policy considerations' ${ }^{103}$ By 1962, Dillon agreed with Galbraith and others that a tax cut was good policy and could give the economy precisely the kind of boost that it needed. However, he had also won over the President and Galbraith to his view that the CEA's 'more extreme measures' should be held 
off at least until after the mid-term elections in order to 'not frighten the financial groups'. ${ }^{104}$

In January 1963, Kennedy and Dillon launched a charm offensive aimed at reassuring European and domestic audiences about the tax cut. In his State of the Union address, Kennedy emphasized the strength of transatlantic cooperation on monetary issues and explained how the tax cut was a necessary step to kick-start the domestic economy in order to reduce the budget deficit. He reiterated his underlying objective of attaining budgetary balance once the economy was performing as it should. To the IMF, Dillon repeatedly emphasized the 'firmness of [the administration's] decision' to balance the budget as soon as feasible contrary to the line 'some of our financial press and banking community have been peddling. ${ }^{105}$

Throughout 1963, Dillon and Kennedy took a more pedagogical approach in order to sell the tax cut and its underlying economic principles. Speaking to the American Bankers Symposium on Economic Growth in February 1963, Kennedy 'hope[d] that all groups would put the national interest first' as he explained that a tax cut could be beneficial for 'fiscal responsibility, equity and efficiency - but above all, [would be] in the interest of economic growth.' As bankers, he told them, they should 'understand better than most people that debt' could be undertaken 'for gainful purposes'. ${ }^{106}$ Nonetheless, the President repeated that 'everything hangs on us, everything hangs upon our maintaining our economy effectively and maintaining [...] discipline. ${ }^{107}$

As he did with the French, Dillon encouraged the view that the administration was fiscally conservative in order to stave off a possible attack on the dollar and in order to coopt businesspeople and thus congressmen to the administration's line. In their speeches, he and Kennedy sought to 'placate fears concerning deficit spending and inflationary tendencies. ${ }^{108}$ Dillon reassured audiences that the deficits were only for a 'brief transitional period' and that the 'President has emphatically committed' to 'a course of intensive expenditure control.' ${ }^{109}$ He emphasized that civilian expenditures had largely been limited to defense and space, the type of spending they might be more inclined to support.

As part of its public relations efforts, the administration also set up a Business Committee for Tax Reduction. The committee included major business figures most notably its Chairmen Henry Ford II, the railway scion Stuart Saunders and its Vice-Chairman David Rockefeller. Recognizing that 'tax credit has all the sex appeal of a 300lb. grandmother', the 
administration used these men to advance their message to others in the business world and in the key congressional committees, including the Senate Finance Committee and the House Ways and Means Committee. ${ }^{110}$

In some respects, Rockefeller was the most important and interesting of all. Dillon's long-standing relationship with the Rockefeller brothers had continued in his time in government. During the Eisenhower administration, John D. Rockefeller had corresponded with Dillon about creating public-private partnerships to address international development needs. ${ }^{111}$ In the Kennedy administration, David Rockefeller had expressed a similar interest with respect to Latin America. He ultimately became a flagbearer for Dillon's bridge-building efforts on tax as well as the balance of payments. To be fair, he was predisposed to this role before Dillon came calling. He was an internationalist and intellectual businessman who championed ideas about responsible business. In a speech, he explained that 'one of the foremost tasks we shall face in the future is the building of sufficiently competent, broadgauged and imaginative leaders of business' who 'feel a responsibility to society which goes beyond the maximizing of profits for their shareholders. ${ }^{112}$ Elsewhere, he wrote that 'the businessman still must learn to communicate more effectively with several groups, foremost among them his opposite numbers in labor and government. ${ }^{\prime 13}$

He was able to put his ideas to practice during the Kennedy administration. At a dinner held in French Culture Minister André Malraux's honor, the President asked Rockefeller for his views on the administration's economic policy. Within weeks, Rockefeller obliged with his insight, including the point that the United States could not 'have our cake and eat it too - that taxes can be reduced even while the government expenditures increase.' He added, 'bankers here and abroad look with concern on recent fiscal policy in our country and worry actively about the future of the dollar' even while he applauded the Treasury 'for thinking ahead'. ${ }^{114}$

About three weeks later, in a letter drafted by Dillon, Kennedy replied. On the balance of payments problems, Kennedy emphasised the need for cooperation: 'we know we cannot solves this problem alone - and other free nations know that they, too, cannot afford any weakness in the dollar, which is the very foundation of the international monetary system. ${ }^{115}$ In a nod to the more conservative sub-text of Rockefeller's letter, he pressed the need for a tax cut while emphasizing that it 'does not, however, diminish the need for strict control of budget expenditures - and I have found it desirable to trim the 
budget request of various departments and agents by several billion dollars each year. ${ }^{116}$ In other words, Kennedy was not the fiscally irresponsible bogeyman that bankers imagined.

Although the exchange was initially private, Dillon saw in it an opportunity to showcase constructive dialogue between the administration and business. In a phone conversation with Dillon, the newspaper magnate Henry Luce agreed and suggested that publishing the letters in Life Magazine would 'dampen down this irrational and emotional hostility.' Dillon enthused, 'That's what so good about the letter from Rockefeller. It is rational. ${ }^{117}$ Dillon repeated this language to Rockefeller when he sought his approval, noting that the letters represented an 'example of a constructive dialogue between business and the government instead of this radical, emotional stuff. ${ }^{\prime 18}$ Publishing the letters encouraged the view that successful businessmen could be supportive of the administration and put the Treasury Department's more fiscally conservative positions on paper as administration policy.

The published exchange was widely-praised and both Dillon and Rockefeller received a stream of congratulatory letters. Rockefeller continued to help the administration well into the fall of 1963 as the battle over the tax cut bill was held up by Senator Harry Byrd in the Senate Finance Committee. At the behest of Henry Ford, Rockefeller forwarded a committee pamphlet to his network emphasizing the 'economics and prudent control of federal expenditures' that underpinned the tax cut. ${ }^{119}$

Nevertheless, as the administration started to look forward to the 1964 election, Galbraith and others reignited fears about a politically-motivated run on the dollar. Galbraith warned Kennedy that 'private holders and bankers are conservatives and some of them cynical reactionaries.' He explained, 'there is a highly plausible chance of deliberate withdrawals by this group at the behest of American conservatives in order to embarrass the Administration in an election year' and that the 'Rockefellers, Goldwater' and others would 'relate the whole to financial irresponsibility.' Galbraith argued that confidence, as Dillon encouraged for bankers and Europeans, was not enough. He maintained that the administration should also attack what was ultimately 'cynical' and politically-motivated 'propaganda'. ${ }^{120}$ Dillon responded that Galbraith's letter was 'an amazing mixture of truth and fantasy which is difficult to disentangle' and that while he was right that Republicans might make the balance of payments an electoral issue, existing measures (including confidence-building steps) were the best antidote. ${ }^{121}$ 
Whereas in the Kennedy administration, Dillon was quick to dismiss Galbraith's fears, he changed his tune in the Johnson administration and began to play up the threat that Republicans might seek to embarrass the President in an election year. ${ }^{122}$ By March 1964, confronted with a President who was uninterested in the economic issues at hand, Dillon encouraged Johnson to meet with the business groups that Kennedy and he had created. ${ }^{123}$ Facing a President and entourage who seemed to scorn bankers, Dillon defended David Rockefeller and forwarded a complimentary article to Johnson adding 'this portrays the man as I know him. ${ }^{, 124}$ Observers rightly celebrated Johnson for passing Kennedy's tax cut legislation and for his deftness in dealing with Congress. For a time, he also reaped the benefits of the steps undertaken to alleviate the balance of payments deficit and to placate fears among dollar holders. However, the irony, as Dillon sensed, was that Johnson was, in fact, the embodiment of the fears that they had expressed about Kennedy, in particular about his lack of fiscal discipline.

Dillon and Roosa's departure from government alone does not explain the eventual collapse of the Bretton-Woods system and the unravelling of the 'bargains' that had sustained postwar economic cooperation. Part of the explanation for the collapse of economic cooperation necessarily lies in structural causes and includes the fact that Johnson's domestic policies and his war spending provoked inflationary pressures. At the same time, as others have noted, collapse was perhaps not inevitable and 'moral suasion' mattered. ${ }^{125}$ The economic problems during the Johnson administration were also important in so far as they signaled a changed economic perspective at the top of the executive. Thinking counterfactually, perhaps a President that was more interested in economics, and specifically in more conservative economic views such as those espoused by Dillon, might have made different choices. Also, if the President had continued to maintain more fiscal discipline, perhaps he could have continued to secure cooperation from the same actors that eventually attacked the Bretton-Woods system.

The article contributes to understanding why cooperation from the private sector and France was possible in earlier years. It informs our understanding of Dillon's special place during the Kennedy administration when he played a preeminent role internally as well as externally since he was welcomed in groups that subsequently proved to be antagonistic. He was able to draw on friendships in the French Finance Ministry and in the 
business world to great effect. He conveyed an image of bipartisanship that protected Kennedy and he shaped the administration's message towards a more fiscally conservative position that placated fears among dollar holders, thus giving the administration breathing room in which to explore reform of the international monetary system. Finally, he had privileged access to Kennedy and trumped many of his colleagues, notably in the State Department and the CEA, in determining economic policies.

All this changed under Johnson who was less inclined to listen to Dillon or to consider economic views that conflicted with his New Deal ambitions. However, Dillon's impatience with Johnson was shared in France and also explains de Gaulle's attack on the dollar's role. Ultimately, in the Kennedy administration, Dillon represented a physical and intellectual bridge between the administration and problematic groups. Frustrating Kennedy's liberal advisors, Dillon ensured that these groups' views were represented within the administration. With Johnson, the bridge faltered and the connection broke.

\section{Figure captions:}

Figure 1: President John F. Kennedy and Secretary of the Treasury C. Douglas Dillon, 1 May 1961. Credit: Abbie Row, White House Photographs, JFKL. https://www.jfklibrary.org/AssetViewer/Archives/JFKWHP-AR6549-B.aspx

Figure 2: President John F. Kennedy addresses American Bankers Association Symposium on Economic Growth with David Rockefeller to his left, 25 Feb. 1963. Credit: Abbie Rowe, White House Photographs, JFKL. https://www.jfklibrary.org/AssetViewer/Archives/JFKWHP-AR7734-I.aspx

\footnotetext{
${ }^{1}$ Barry Eichengreen, Globalizing Capital: A History of the International Monetary System (Princeton, Princeton University Press, 2008), 126.

${ }^{2}$ As described by Barry Eichengreen, see: Barry Eichengreen, 'From Benign Neglect to Malignant Preoccupation: U.S. Balance-of-Payments Policy in the 1960s' in George Perry and James Tobin (eds.), Economic Events, Ideas and Policies: The 1960s and After (Washington D.C., The Brookings Institution, 2000). By contrast, John Odell calls the period a 'major non-crisis turning point'. John S. Odell, U.S. International Monetary Policy: Markets, Power, and Ideas as Sources of Change (Princeton, Princeton University Press, 1982), 161.

${ }^{3}$ David P. Calleo, 'De Gaulle and the Monetary System: the Golden Rule' in Robert O. Paxton and Nicholas Wahl (ed.), De Gaulle and the United States (Oxford, Berg Publisher, 1994); Francis J. Gavin and Erin Mahan, 'Hegemony or Vulnerability? Giscard, Ball, and the 1962 Gold Standstill Proposal', Journal of European Integration History, 6:2 (Dec. 2000), 61-84.

${ }^{4}$ Robert Triffin, 'Sterling, the Dollar, de Gaulle and Gold', Challenge 13:4 (April 1965), 22.
} 
See also Christopher S. Chivvis, 'Charles de Gaulle, Jacques Rueff and French International Monetary Policy under Bretton Woods', Journal of Contemporary History 41:4 (Oct. 2006), 716.

${ }^{5}$ Frank Costigliola, France and the United States: The Cold Alliance Since World War II (New York, Twayne Publishers, 1992), 149. For similar arguments, see especially: Calleo, 'The Golden Rule'; Vincent Jauvert, L'Amérique control De Gaulle: histoire secrete, 1961-1969 (Paris, Seuil, 2000); Lawrence S. Kaplan, 'McNamara, Vietnam and the defense of Europe' in Vojtech Mastny, Sven G. Holtsmark and Andreas Wenger (eds), War Plans and Alliance in the Cold War: Threat perceptions in the East and West (Oxford, Routledge, 2006); Richard F. Kuisel, Seducing the French: The Dilemma of Americanization (Berkeley, University of California Press, 1993); Erin Mahan, Kennedy, De Gaulle and Western Europe (London, Palgrave Macmillan, 2002); Garret Martin, General de Gaulle's Cold War: Challenging American Hegemony, 1963-1968 (New York, Berghahn Books, 2013); Paxton and Wahl, De Gaulle and the United States; Sebastian Reyn, The American Experience with De Gaulle, 19581969 (Amsterdam, Amsterdam University Press, 2010); March Trachtenberg, Between empire and alliance: America and Europe during the Cold War (Lanham, Rowman \& Littlefield, 2003); Maurice Vaisse, La grandeur: politique étrangère du Général de Gaulle 1958-1969 (Paris, Fayard, 1998).

${ }^{6}$ Costigliola, France and the United States, 144.

${ }^{7}$ Francis J. Gavin, Gold, Dollars and Power: The Politics of International Monetary Relations (Chapel Hill, University of North Carolina Press, 2004).

${ }^{8}$ Chivvis, 'De Gaulle, Rueff'; Chivvis, 'De Gaulle and the Dollar' in Benjamin M. Rowland (ed.), Charles de Gaulle's Legacy of Ideas (Plymouth, Lexington Books, 2011).

${ }^{9}$ Odell, U.S. International Monetary Policy, 131-2.

${ }^{10}$ Gavin and Mahan, Hegemony or Vulnerability.

${ }^{11}$ Two books are dedicated solely to the topic, both written in the 1960s: Jim F. Heath, John F. Kennedy and the business community (Chicago, University of Chicago Press, 1969); Hobart Rowen, The free enterprisers: Kennedy, Johnson, and the business establishment (New York, Putnam, 1969). Also, on economic relations in general: Seymour Edwin Harris, Economics of the Kennedy years, and a look ahead (New York, Harper \& Row, 1964).

${ }^{12}$ Robert Sobel, The Life and Times of Dillon Read (New York, Penguin, 1991), 293.

${ }^{13}$ Dillon to White House Committee on Mutual Security Program, 20 Feb. 1959, [U.S.] D[eclassified] D[ocuments] O[nline], accessed online 16 Feb. 2016: http://tinyurl.galegroup.com/tinyurl/356mU7.

${ }^{14}$ C. Douglas Dillon oral history interview no. 1 by Dixon Donnelley, 25 Jan. 1965, J[ohn] F. K[ennedy $\mathrm{P}$ [residential] L[ibrary], 6.

${ }^{15}$ Dillon oral history interview no. 10 by Professor Seymour Harris, 20 Aug. 1964, JFKL, 203; Dillon oral history interview by Robert D. Shulzinger, 29 April 1987, Association for Diplomatic Studies and Training, Foreign Affairs Oral History Project, 5; Sobel, Dillon Read, 211.

${ }^{16}$ Senator John F. Kennedy and Hon. Douglas Dillon, "Press conference at Kennedy Residence, Washington D.C", 16 Dec. 1960, JFKL, Pre-Presidential Papers, Presidential Campaign Files, Box 1060, Folder: Washington D.C. with Douglas Dillon.

${ }^{17}$ John Kenneth Galbraith to Kennedy, Oct. 20, 1960 in John Kenneth Galbraith, Letters to Kennedy (Cambridge, MA: Harvard University Press, 1998), 29.

${ }^{18}$ Arthur M. Schlesinger, A Thousand Days: John F. Kennedy in the White House (New York, First Mariner Books, 1965), 134.

${ }^{19}$ McKinsey Study: Treasury Department, Dec. 1960, JFKL, P[re-]p[residential] p[apers], Transition Files, Box 1075, Folder: McKinsey study.

${ }^{20}$ Schlesinger, A Thousand Days, 93.

${ }^{21}$ Ibid., 136.

22 Ibid., 93.

${ }^{23}$ Senator Albert Gore oral history interview no. 1 by Seth Tilman, 13 and 21 Aug. 1964, JFKL, 8.

${ }^{24}$ Arthur M. Schlesinger, Journals: 1952-2000 (New York, Penguin, 2008), 134.

${ }^{25}$ Senator Albert Gore oral history interview no. 1 by Seth Tilman, 13 and 21 Aug. 1964, JFKL, 8. 
${ }^{26}$ Seymour Harris to Robert Kennedy, undated, JFKL, R[obert] [F]. [K]ennedy Papers, Box 236, Folder: Seymour Harris.

27 "Economic Trio", The Economist, 23 Feb. 1963, 69.

${ }^{28}$ C. Douglas Dillon, "The Developing Strength of the International Monetary System", The Department of State Bulletin, LI: 1318 (Sept. 28, 1964), 448.

${ }^{29}$ Michael Bordo, 'The Bretton Woods International Monetary System: A Historical Overview' in Michael Bordo and Barry Eichengreen (eds.), A Retrospective on the Bretton Woods System (Chicago, Chicago University Press, 1993), 59; Mahan, Kennedy and de Gaulle, 115.

${ }^{30}$ Robert Triffin, 'Gold and the Dollar Crisis: Yesterday and Tomorrow', Essays in International Finance, 132 (Dec. 1978), 13-5.

${ }^{31}$ Tape 110, 11 Sept. 1963, Balance of Payments, JFKL, P[resident's] O[ffice] F[iles], Presidential Recordings.

${ }^{32}$ Dillon to President Kennedy, 5 July 1961, POF, D[epartments] and A[gencies], Box 89, Folder: Treasury, 1961: July-Aug.

${ }^{33}$ Dillon and Walter Heller, 24 March 1961, JFKL, C. Douglas [Dillon papers], Tel[ephone] Con[versation Memoranda] Series, Box 37, Folder: March-April 1961, Folder 1 of 2.

${ }^{34}$ Tape 110, JFKL, POF, Presidential Recordings.

${ }^{35}$ C. Douglas Dillon oral history no. 4 by Elspeth Rostow, 4 Aug. 1964, JFKL, 66.

${ }^{36}$ Dillon to President Kennedy, 11 Feb. 1963, JFKL, POF, D\&A, Box 90, Folder: Treasury, Feb. 1963.

${ }^{37}$ Dillon with Robert McNamara, 3 Sept. 1962, JFKL, Dillon papers, Telcon Series, Box 38, Folder: 2 of 2, Aug.-Sept. 1962.

${ }^{38}$ Gore oral history, JFKL, 9.

${ }^{39}$ Chris McNulty, 'In the Doghouse: John F Kennedy, the Yale Commencement Speech, and Business Relations in 1962' (Masters dissertation, London School of Economics, 2016).

${ }^{40}$ Dillon to President Kennedy, 31 Aug. 1961, US Department of the Treasury, DDO, accessed online 16 Feb. 2016: http://tinyurl.galegroup.com/tinyurl/356991.

${ }^{41}$ Dillon to President Kennedy, 3 Oct. 1961, JFKL, POF, D\&A, Box 89, Folder: Treasury, 1961, Oct.Dec.

${ }^{42}$ Dillon to President Kennedy, 3 July 1962, JFKL, Dillon papers, Box 38, Folder: July-Aug. 1962.

${ }^{43}$ Dillon to President Kennedy, 5 July, 1962, US Department of the Treasury, DDO, accessed online 16 Feb. 2016: http://tinyurl.galegroup.com/tinyurl/3569AX.

${ }^{44}$ Dillon to President Kennedy, 3 July 1962, JFKL, Dillon papers, Box 38, Folder: July-Aug. 1962.

${ }^{45}$ See, for instance: Dillon to President Kennedy, 5 July 1961, JFKL, POF, D\&A, Folder: Treasury, 1961, July-Aug.

${ }^{46}$ Robert Roosa, The Dollar and World Liquidity (New York, Random House, 1967), 10.

${ }^{47}$ Dillon oral history no. 1, JFKL, 3.

${ }^{48}$ Seymour Harris to Dillon, 25 Aug. 1961, US Department of State, DDO, accessed online 16 Feb. 2016: http://tinyurl.galegroup.com/tinyurl/356BUX.

${ }^{49}$ Dillon to President Johnson, 25 Nov. 1963, JFKL, Dillon papers, Box 46, Folder: 1 of 2, Misc. 1/63$10 / 63$.

${ }^{50}$ C. Douglas Dillon oral history interview no. 1 by Larry J. Hackman, JFKL, Robert F. Kennedy collection, 25.

${ }^{51}$ Schlesinger, Journals, 207.

${ }^{52}$ Dillon to President Johnson, 30 Nov. 1963, JFKL, Dillon Papers, Series: Memoranda to the President, Box 35, Folder: Sept.-Dec. 1963.

${ }^{53}$ See especially: Francis J. Gavin, Nuclear Statecraft: History and Strategy in America's Atomic Age (Ithaca, Cornell University Press, 2012).

${ }^{54}$ Dillon to President Johnson, 18 Dec. 1963, JFKL, Dillon Papers, Series: Memoranda to the President, Box 35, Folder: Dec. 1963. 
${ }^{55}$ Dillon with Bill Moyers, 2 June 1964, JFKL, Dillon papers, Telcon Series, Box 38, Folder: 6 of 6, Oct.Dec. 1963.

${ }^{56}$ Dillon with Francis Bator, 8 Jan. 1965, JFKL, Dillon papers, Telcon Series, Box 40, Folder: 2 of 3 , Jan.-March 1965.

${ }^{57}$ Dillon with Gardner Ackley, 4 Feb. 1965, JFKL, Dillon papers, Telcon Series, Box 40, Folder 2 of 3, Jan.-March 1965.

${ }^{58}$ Dillon to President Johnson, 1 Feb. 65, JFKL, Dillon papers, Series: Memoranda to the White House, Box 37, Folder: Feb. 1965.

${ }^{59}$ Dillon with McGeorge Bundy, 27 Jan. 1965, JFKL, Dillon papers, Telcon Series, Box 40, Folder: 1 of 3, Jan. 65.

${ }^{60}$ Dillon with Henry Ford, 11 Feb. 1963, JFKL, Dillon papers, Telcon Series, Box 38, Folder: 2 of 3.

${ }^{61}$ Gavin and Mahan, Hegemony or Vulnerability.

${ }^{62}$ President Charles de Gaulle, "Conférence de presse du 4 février 1965", Institut national de I'audiovisuel, accessed online 17 Oct. 2016: http://bit.ly/2eGuxjP.

${ }^{63}$ Mahan, Kennedy and de Gaulle, 111.

${ }^{64}$ Dillon to President Kennedy, 11 March 1962, JFKL, POF, D\&A, Box 89, Folder: Treasury, 1962: March-April.

${ }^{65}$ Meetings: Tape 98/A34. Balance of Payments, 15 July 1963, JFKL, POF, Presidential Recordings.

${ }^{66}$ President de Gaulle to Dillon, 6 May 1960 in Charles de Gaulle, Lettres, Notes et Carnets: Juin 1958-Décembre 1960 (Paris, Plon, 1985), 354-5.

67 "Some thoughts on Gaullist France", Dillon to President Johnson, undated (1965), US Department of the Treasury, DDO, accessed online 16 Feb. 2016: http://tinyurl.galegroup.com/tinyurl/3566o3. ${ }^{68}$ Dillon to Wilfrid Baumgartner, 2 June 1961, JFKL, Dillon papers, Box 46, Folder: Misc; Dillon to Valéry Giscard d'Estaing, 2 March 1964, JFKL, Dillon papers, Box 65, Folder: Bonn, Vienna, London, March-May 1964.

${ }^{69}$ Dillon to President Kennedy, 22 May 1961, JFKL, POF, D\&A, Box 88, Folder: Treasury 1961: MarchMay.

70 'Dillon Calendar 14-16 June 1964', JFKL, Dillon papers, Box 65, Folder: Paris, France, June 13-16 1964.

${ }^{71}$ Dillon to President Kennedy, 22 May 1961, JFKL, POF, D\&A, Box 88, Folder: Treasury 1961: MarchMay.

72 Dillon to President Kennedy, 25 May 1962, JFKL, POF, D\&A, Box 89, Folder: Treasury: May 1962. For an interpretation of this interaction as a threat, see Janick Marina Schaufelbuehl, 'Gold as a Diplomatic Tool: How the Threat of Gold Purchases Worked as Leverage in International Monetary Relations, 1960-1968' in Sandra Bott (ed.) The Global Gold Market and the International Monetary System from the late $19^{\text {th }}$ Century to the Present (London, Palgrave, 2013), 168.

${ }_{73}$ Dillon to President Kennedy, 25 May 1962, JFKL, POF, D\&A, Box 89, Folder: Treasury: May 1962.

${ }^{74}$ Costigliola, France and the United States, 130.

${ }^{75}$ Dillon with Roswell Gilpatric, 9 April 1962, JFKL, Dillon Papers, Telcon Series, Box 38, Folder: 1 of 3: April-June 1962, Box 38.

${ }^{76}$ Dillon with McNamara, 12 March 1962, JFKL, Dillon Papers, Telcon Series, Box 38, Folder: 3 of 3: Jan-March 1962.

${ }_{77}$ Dillon to President Kennedy, 25 Jan. 1963, JFKL, POF, D\&A, Box 90, Folder: Treasury, Jan. 1963.

${ }^{78}$ Robert Roosa to Dillon, 18 Dec. 1961, JFKL, POF, D\&A, Box 89, Folder: Treasury, 1961: Oct.-Dec.

${ }^{79}$ President Kennedy to Cabinet Committee on balance of payments, 2 March 1963, JFKL, POF, D\&A, Box 90, Folder: Treasury: March 1963.

80 'Report to the President by the Secretary of the Treasury on the Balance of Payments', Dillon to President Kennedy, 26 March 1962, JFKL, POF, D\&A, Box 89, Folder: Treasury: March-April 1962.

${ }^{81}$ President Kennedy, 'Q\&A at American Bankers Symposium on Economic Growth', 25 Feb. 1963, JFKL, White House Audio Recordings, 1961-1963, WH-165-006. 
${ }^{82}$ Dillon with Giscard, June 7, 1963, JFKL, Dillon papers, Telcon Series, Box 38, Folder: 3 of 4, AprilJuly 1963.

83 'Report on European Trip', Dillon to President Johnson, 26 May 1964, US Department of the Treasury, DDO, accessed online 16 Feb. 2016: http://tinyurl.galegroup.com/tinyurl/357Qv3.

${ }^{84}$ Roosa report to Group of 10, 5 Jan. 1964, JFKL, Dillon papers, Box 47, Folder: Jan. 1964.

${ }^{85}$ Kuisel, Seducing the French, 68.

${ }^{86}$ David Rockefeller, Memoirs (New York, Random House, 2003), 198.

${ }^{87}$ Ibid., 210.

${ }^{88}$ Tape 110, JFKL, POF, Presidential Recordings.

${ }^{89}$ Galbraith to President Kennedy, 31 May 1962 in Galbraith, Letters to Kennedy, 49.

${ }^{90}$ Harris, Economics of the Kennedy Years, 50.

${ }^{91}$ Dillon oral history interview no. 2 by Dixon Donnelley, 10 Nov. 1964, JFKL, 37.

92 Dillon, 'Remarks to Financial Writers Association', 7 June 1962, JFKL, POF, Press Conferences, Box 56, Folder: 1 of 2, Background materials.

${ }^{93}$ Ralph Bollard to Dillon, 13 April 1962, JFKL, POF, D\&A, Box 89, Folder: Treasury, May 1962.

${ }^{94}$ Schlesinger, A Thousand Days, 638.

95 Joseph Barr to Dillon, 24 Nov. 1961, JFKL, POF, D\&A, Box 89, Folder: Treasury, 1961: Oct.-Dec..

${ }^{96}$ Entry June 17, 1962 in Schlesinger, Journals, 157.

97 'The Economy: The Day of the Bear', Time Magazine, 8 June 1962, cover.

98 'The Other Side of the Ledger', Wall Street Journal, 15 Jan. 1963, 18.

${ }^{99}$ Dillon to President Kennedy, 13 July 1962, JFKL, POF, D\&A, Box 89, Folder: Treasury, July 1962, 115.

${ }^{100}$ Dillon with President Kennedy, 8 May 1962, JFKL, Dillon Papers, Telcon Series, Box 38, Folder:

April-June 1962.

${ }^{101}$ Schlesinger, A Thousand Days, 648.

102 Dillon to Robert Kennedy, 5 July 1962, JFKL, Dillon papers, Box 25, Folder: 4 of 6.

${ }^{103}$ Seymour Harris to Dillon, 7 June 1962, JFKL, POF, D\&A, Box 89, Folder: Treasury, June 1962.

${ }^{104}$ Galbraith to President Kennedy, 6 June 1962, JFKL, POF, Press Conferences, Box 56, Folder: 1 of 2:

7 June 1962, Background materials; Harris to President Kennedy, 27 Sept. 1962, JFKL, POF, D\&A, Box 90, Folder: Treasury, Sept. 1962.

${ }^{105}$ Dillon, 'Remarks to the Annual Meeting of the IMF', 25 Sept. 1961, JFKL, POF, D\&A, Box 89, Folder: Treasury, Sept. 1961.

${ }^{106}$ President Kennedy, 'Remarks at American Bankers Symposium on Economic Growth', 25 Feb. 1963, JFKL, POF, Speech File, Box 43, Folder: Remarks at American Bankers Symposium.

${ }^{107}$ President Kennedy, 'Q\&A at American Bankers Symposium on Economic Growth', 25 Feb. 1963, JFKL, White House Audio Recordings, 1961-1963, WH-165-006.

108 'Analysis of Recent Editorial Comment on the President's Tax Proposals', Treasury Department, 29 May 1963, JFKL, POF, D\&A, Box 90, Folder: Treasury, June 1963.

${ }^{109}$ Dillon, 'Speech delivered before the American Bankers Association, Washington D.C.: Tax Reduction and Balanced Budget', 8 Oct. 1963, Vital Speeches of the Day, 30:2 (Nov. 1963), 44. ${ }^{110}$ Dillon with President Kennedy, 1 June 1962, JFKL, Dillon papers, Telcon Series, Box 38, Folder: April-June 1962,

${ }^{111}$ John D. Rockefeller to Dillon, April 28, 1958, R[ockefeller] A[rchive] C[enter], RG5, Series 1, Box 27, Folder: 230

${ }^{112}$ David Rockefeller, 'The Aspirations of Mankind in a Troubled World: speech delivered to the International Industrial Conference, San Francisco', 17 Sept. 1965, Internet Archive, accessed online 17 Oct. 2016: http://bit.ly/2eBmigo.

${ }^{113}$ David Rockefeller, 'The Changing Role of Business in Our Society', Proceedings of the American Philosophical Society, 107:2 (15 April 1963), 114. 
${ }^{114}$ David Rockefeller to President Kennedy, 5 June 1962, RAC, Collection: R[ockefeller] \& A[ssociates general files], RG 3, Box 483, Folder: JFK and DR exchange.

${ }^{115}$ President Kennedy to David Rockefeller, 26 June 1962, RAC, Collection: R\&A, RG 3, Box 483, Folder: JFK and DR exchange.

116 Ibid.

${ }^{117}$ Dillon with Henry Luce, 21 June 1962, JFKL, Dillon papers, Telcon Series, Box 38, Folder: AprilJune 1962.

${ }^{118}$ Dillon with David Rockefeller, 21 June 1962, JFKL, Dillon papers, Telcon Series, Box 38, Folder: April-June 1962.

${ }^{119}$ Henry Ford to David Rockefeller, 10 Sept. 1963, R\&A, RG 3, Box 218, Folder: Economics - taxes.

${ }^{120}$ Galbraith to President Kennedy, 19 Sept. 1963, JFKL, Dillon papers, Series: Memoranda to the President, Box 35, Folder: Sept. 1963.

${ }^{121}$ Dillon to President Kennedy, 23 Sept. 1963, JFKL, Dillon papers, Series: Memoranda to the President, Box 35, Folder: Sept. 1963.

${ }^{122}$ Dillon to President Johnson, 18 Dec. 1963, JFKL, Dillon papers, Series: Memoranda to the President, Box 35, Folder: 2 of 2, Nov.-Dec. 1963.

${ }^{123}$ Dillon to President Johnson, 11 March 1964, Dillon papers, Series: Memoranda to the President, Box 35, Folder: March 1964.

${ }^{124}$ Dillon to President Johnson, 13 Jan. 1965, Dillon papers, Series: Memoranda to the President, Box 35, Folder: Jan. 1965.

${ }^{125}$ Bordo, 'The Bretton Woods International Monetary System', 85. In addition to Bordo, the term 'moral suasion' was used by both Dillon and Galbraith during a long Cabinet meeting on the balance of payments, Tape 110, JFKL, POF, Presidential Recordings. 